\title{
Changes In The Financial System Stability Of Asean Founder Countries Due To Covid-19
}

\author{
Rusiadi $^{*}$, Anwar Sanusi ${ }^{2}$, Ade Novalina $^{3}$, Milenia M Tafonao $^{4}$, Audre Aprillia $^{5}$ \\ 1,2,3,4,5 Universitas Pembangunan Panca Budi \\ * Corresponding author: \\ Email: rusiadi@dosen.pancabudi.ac.id
}

\begin{abstract}
The threat of the spread of coronavirus to economic growth and inflation in countries in the world will also seep into the global and domestic macrofinancial sector. This research was conducted to analyze how the level of change in the stability of the financial system of ASEAN Founders (ASEFO) with the emergence of the covid 19 pandemic. This study used secondary data (time series) in asefo countries. The model used is a different test model paired sample t-test. The results of the analysis showed that the Covid 19 pandemic had a significant effect on the stability of the financial system with the ASEFO State NPL indicator.
\end{abstract}

Keywords: Covid-19, Financial System Stability

\section{INTRODUCTION}

Now the world is in an uproar by the covid 19 outbreak that almost paralyzed the activities of the world community. The Ministry of Health informs that the virus, which originated in Wuhan City, China, is a large family of viruses that cause diseases in animals and humans where in humans usually cause respiratory infections, ranging from the common cold to serious diseases such as Milddle East Respiratory Syndrome (MERS). The size of the global economy in 2020 can not only be on the scope of the economy itself, but economic instability in a country even on a global scale can arise due to the Corona Virus (Burhanuddin and Abdi, 2020). So great is the rate of addition of covid 19 cases every day in the world. Here is the data on the world's covid 19 cases at the end of each month since its spread in 2020:

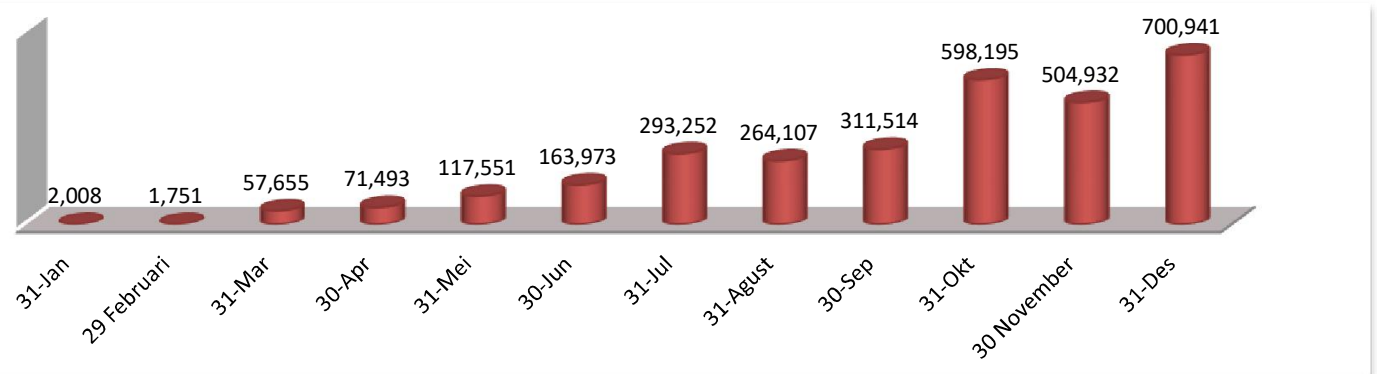

Fig 1.1. Number of New Cases of Covid 19

How quickly the spread of the corona virus throughout the world and continues to grow every day since January 2020. This pandemic has raised considerable concern for the entire world community. Even in Wardhana (2020) it was revealed that Indonesia's economic development, which has already reached the path to the status of a middle-high income country, is in danger of collapsing and must be restarted, as was the case 10-20 years ago. ASEFO countries as China's second largest trading partner in 2019 and as members of ASEAN countries with the highest number of Covid 19 cases in July 2020 were also affected just as badly as the country of origin of the pandemic (China). This pandemic has had a negative impact on all sectors including the financial sector. The inflation rate, which is one of the main priorities in the current economy, is also affected. As inflation and the progress of GDP figures have a very close relationship. According to Tambunan (2014) an inflation rate that is too high will have a negative impact on economic growth. During the pandemic, the pattern of inflation movement is also different from usual. The inflation rate at the time of 
welcoming Eid al-Fitr during the Covid 19 pandemic has a trend that tends to decrease. In fact, the inflation rate is very important in supporting economic activity. The following is the development of inflation in ASEFO countries before and during the pandemic:

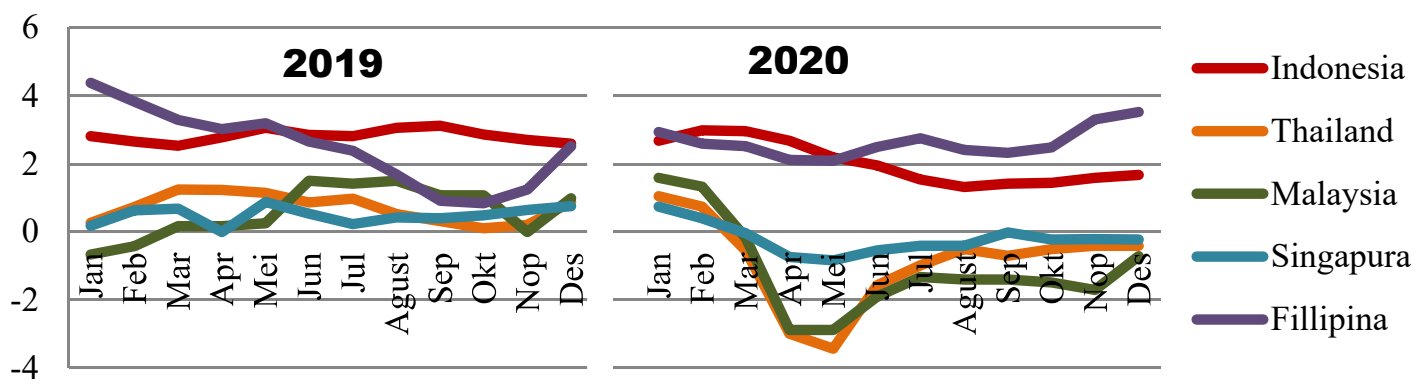

Fig 1.2. Inflation Rate

Sumber: https://www.ceicdata.com /ec/indicator/inflation-consumer-price-index-cpi-growth

The movement of inflation rates in all ASEAN Founder countries (ASEFO) is very volatile. From the data in the table and graph above, it can be seen that the pattern of inflation movement is different from usual. Usually when welcoming major holidays, the inflation rate will increase rapidly, for example during Eid al-Fitr the inflation rate will increase due to an increase in demand for goods and services by the public, so that the level of prices for goods and services also increases. Similar to the inflation phenomenon at the time of welcoming the 2019 Christmas and 2020 New Year celebrations, the inflation rate in these countries tends to rise due to increased public consumption activities in the year-end period.

However, it is different when welcoming Eid al-Fitr during the Covid 19 pandemic, precisely in May 2020, this low inflation rate actually tends to experience a deflationary trend until June 2020. Since entering the year of the covid 19 pandemic, in Indonesia and Singapore the numbers Inflation tends to continue to decline every month. With Thailand and Singapore being the ASEFO countries whose average inflation rate fell the most after the covid 19 pandemic, at $-1.13 \%$ and $-0.148 \%$ respectively in the 6 -month period after the covid 19 pandemic. This slowing inflation rate certainly illustrates a very sluggish economy. Especially from the tourism and transportation sectors, for example, public transportation services which are certainly one of the biggest contributors to deflation. How not, in the midst of this pandemic, most people have minimized activities outside the home including the government's recommendation to stay at home to break the chain of the spread of covid 19.

As the movement of the credit risk ratio value in ASEFO countries which tends to increase during the pandemic:

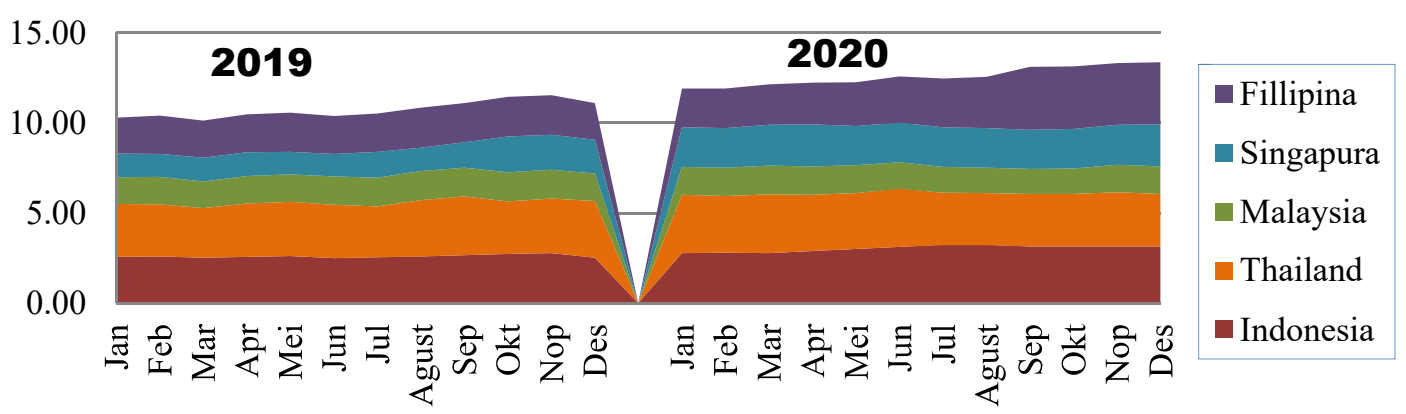

Fig1.3. Non performing loans (\%)

In general, the NPL ratio in ASEAN Founder (ASEFO) countries has increased when entering the pandemic year. In fact, this number has continued to increase from January to June 2020. This shows that the risk of bank credit is getting bigger. Thailand is the country with the largest NPL ratio at 3\% in that period. With Indonesia itself being in the order after Thailand. Thus, resilience policies (combination of fiscal, monetary, macroprudential / microprudential) are very important in preventing economic crises stemming from the financial crisis. 


\section{LITERATURE REVIEW}

The individual or household aims to maximize the utility of holding money. The stock of real money held by individuals or households that is used for consumption and leisure so that the utility function of households to hold money indefinitely is $u\left(c_{t}, l_{t}\right)+\beta u\left(c_{t+1}, l_{t+1}\right)+\beta^{2} u\left(c_{t+2}, l_{t=2}\right)+\ldots$ The household constraint in period $[\mathrm{t}]$ is shown by the inattentive relationship with real consumption and the stock of real money, namely: $1 \mathrm{t}=(\mathrm{ct}, \mathrm{mt})$ where the lazy response to real consumption is negative [_ $\mathrm{c}<0$ ] and the response to real cash is positive [_ $\mathrm{m}>0]$. The equation explains that the amount of slack time and working time is constant. At a certain consumption, working time will decrease if leisure time and real money stock increase. If individuals or households use all of the productive asset facilities, the aggregate production changes to: where $\mathrm{f}(\mathrm{kt}-1)$ describes the aggregate production function of individuals or households. The aggregate production function of individuals or households causes changes in household budget constraints to be: where: $\mathrm{vt}=$ government transfers to individuals or households, and $\mathrm{t}-1=\mathrm{Pt}-1 \mathrm{Pt}-2=$ inflation rate period [ $\mathrm{t}-1]$. In the discussion of the money demand model it has been shown that the FOC of the utility maximization of holding money is

$$
\begin{gathered}
u_{1}\left[c_{t}, \psi\left(c_{t}, m_{t}\right)\right]+u_{2}\left[c_{t}, \psi\left(c_{t}, m_{t}\right)\right] \psi_{1}\left(c_{t}, m_{t}\right)-\lambda P_{t}=u_{2}\left[c_{t}, \psi\left(c_{t}, m_{t}\right)\right] \\
\times\left[\psi_{2}\left(c_{t}, m_{t}\right)\right]-\lambda P_{t}+\lambda P_{t}(1+R)^{-1} \\
\left.u_{2}\left[c_{t}, \psi\left(c_{t}, m_{t}\right)\right] \psi_{2}\left(c_{t}, m_{t}\right)\right]=\left[1-\left(1+R_{t}\right)^{-1}\right]\left\{u_{1}\left[c_{t}, \psi\left(c_{t}, m_{t}\right)\right]+\right. \\
\left.u_{2}\left[c_{t}, \psi\left(c_{t}, m_{t}\right)\right] \psi_{1}\left(c_{t}, m_{t}\right)\right\}
\end{gathered}
$$

Substituting the constraint equation into the above equation will remove $1 \mathrm{t}$ and the left-hand side equation into a function that includes ct and $\mathrm{mt}=\mathrm{Mt} \mathrm{Pt}$, In the period $[\mathrm{t}+1]$ the above equation changes to:

$$
\begin{aligned}
& \frac{u_{2}\left(c_{t}, l_{t}\right) \psi_{2}\left(c_{t}, m_{t}\right)}{u_{1}\left(c_{t}, l_{t}\right)+u_{2}\left(c_{t}, l_{t}\right) \psi_{1}\left(c_{t}, m_{t}\right)}=-\frac{1}{\left[f^{\prime}\left(k_{t}\right)+1\right]\left[1+n_{t}\right]}=-\frac{1}{1+R_{t}} \\
& \frac{u_{1}\left(c_{t}, l_{t}\right)+u_{2}\left(c_{t}, l_{t}\right) \psi_{1}\left(c_{t}, m_{t}\right)}{u_{1}\left(c_{t+1}, l_{t+1}\right)+u_{2}\left(c_{t+1}, l_{t+1}\right) \psi_{1}\left(c_{t+1}, m_{t+1}\right)}=\beta\left[f^{\prime}\left(k_{t}\right)+1\right]=\beta\left[1+R_{t}-\pi_{t}\right]
\end{aligned}
$$

The left side of the above equation describes the ratio of marginal utility and the right side describes $\left[\mathrm{f}^{\prime}(\mathrm{kt})+1\right][1+\mathrm{t}]=\left[1+\mathrm{f}^{\prime}(\mathrm{kt})+\mathrm{t}\right]$ where the value of $\left.\left[-\mathrm{t} \mathrm{f}^{\prime}(\mathrm{kt})\right)\right]$ is relatively small so it can be ignored. The value of $\left[\mathrm{f}^{\prime}(\mathrm{kt})\right]$ is the real rate of return $[\mathrm{rt}]$ and $\mathrm{Rt}=\mathrm{f}^{\prime}(\mathrm{kt})+\mathrm{t}=\mathrm{rt}+\mathrm{t}$ so that the right side of the above equation changes to. The above equation is the ratio of marginal utility to current and future consumption preferences. The marginal utility ratio will decrease as the interest rate rises. An increase in the nominal interest rate [Rt] will decrease current consumption [ct] and increase future consumption [ct +1 ] so that the marginal utility ratio gets smaller. The decrease in current consumption [ct] also means a decrease in the demand for the current stock of real money [mt].

A decrease in current consumption will lower the IS schedule and an increase in the stock of real money will increase the LM schedule, so that aggregate demand falls and the general price level rises. A decrease in aggregate demand and an increase in the general price level will reduce the real consumption of households and the real consumption of firms. This proportion proves that the maximal utility analysis corresponds to the IS and LM analysis. According to Ismail (2009) NPL (Non Performing Loan) is a loan that is in arrears for more than 90 days. Where NPL is divided into Substandard, Doubtful, and Loss Loans. Furthermore, according to Taswan (2006), the ratio used to assess financial performance in managing nonperforming loans is the NPL (Non-Performing Loan) ratio. Non-performing loans are classified into Collectibility, Current, Substandard, Doubtful, and Loss. Thus, Non-performing loans (NPL) are loans that have failed to pay or are close to default. NPL or non-performing loans, in simple terms, will certainly have an impact on reducing the capital owned by a bank. If this is continuously ignored, it will have a wider impact, especially on lending for the next period. For this reason, Bank Indonesia Regulation No.6/10/PBI 2004 dated April 4, 2004 concerning the Rating System for Commercial Banks, stipulates that the ratio of non-performing loans (NPL) is $5 \%$. 


\section{METHODS}

This research is classified as a quantitative study because it uses secondary data with a Paired t-test model approach which will analyze the effect of the COVID-19 pandemic on the stability of the financial system. The research data is ASEFO (ASEAN Founder) country data, consisting of Indonesia, Thailand, Malaysia, Singapore and the Philippines for the period January 2019-December 2020 sourced from CEIC. $\mathrm{http}: / / \mathrm{www}$. ceicdata.com. Based on the theoretical basis and previous research, the following framework is formed for the analysis in this study:

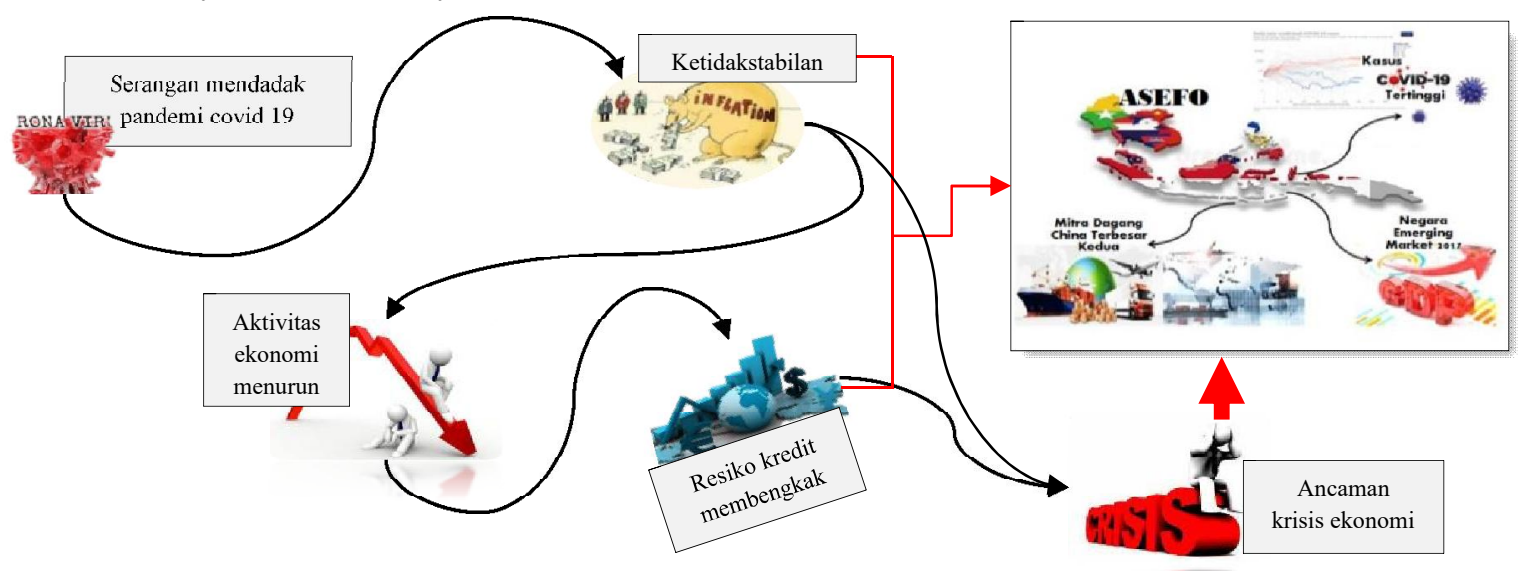

Fig 3.1. Kerangka Berfikir Pengaruh Covid 19 Terhadap Stabilitas Sistem Keuangan

The paired sample T-test was used by researchers to determine the impact of covid-19 on financial system stability in ASEFO countries. Manually the t-test formula used for paired samples is as follows:

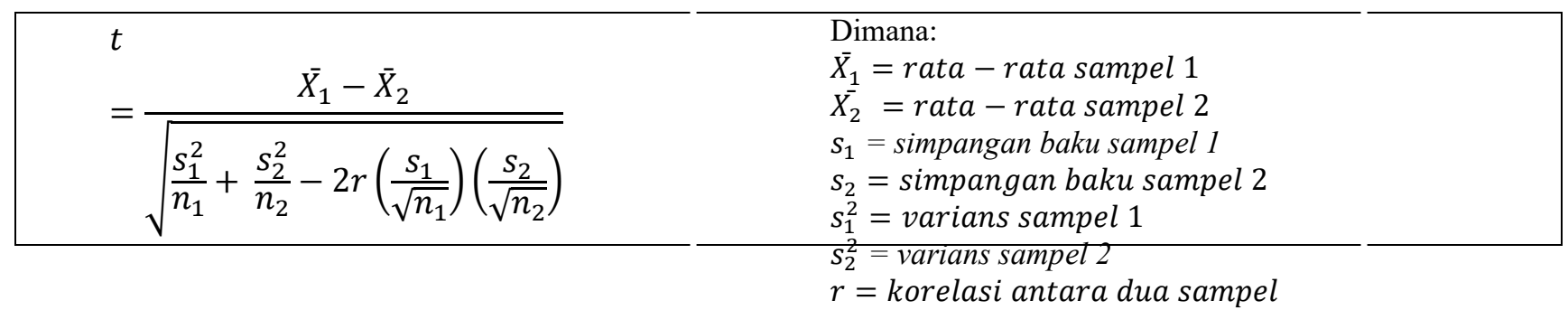

\section{RESEARCH RESULTS AND DISCUSSION}

Tabel 4.1. Output $T$ Test of Inflation

Paired Samples Statistics

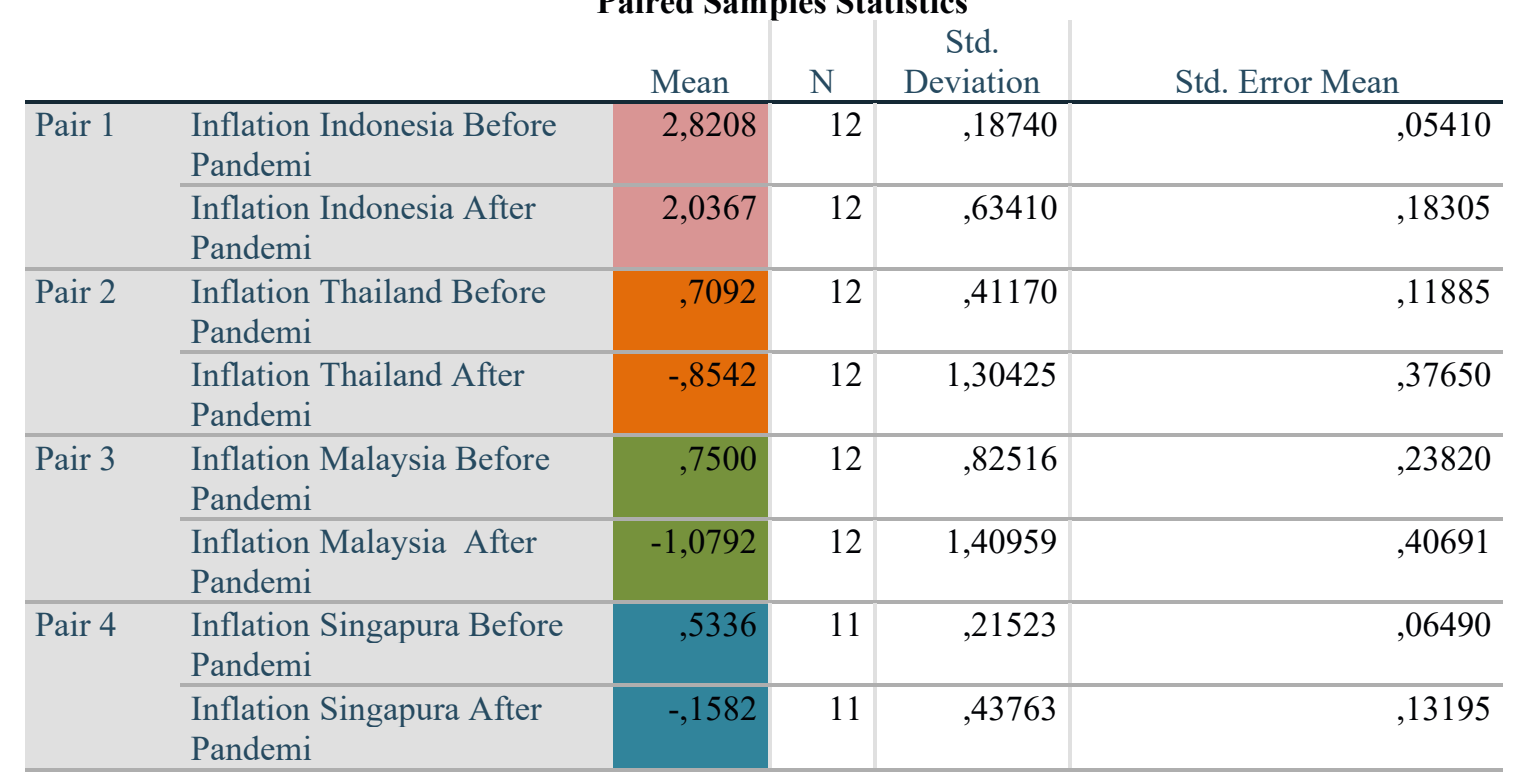




\begin{tabular}{ll|r|r|r|r}
\hline Pair 5 & $\begin{array}{l}\text { Inflation Filipina Before } \\
\text { Pandemi }\end{array}$ & 2,4975 & 12 & 1,13536 &, 32775 \\
\hline $\begin{array}{l}\text { Inflation Filipina After } \\
\text { Pandemi }\end{array}$ & 2,6300 & 12 &, 43880 &, 12667 \\
\hline
\end{tabular}

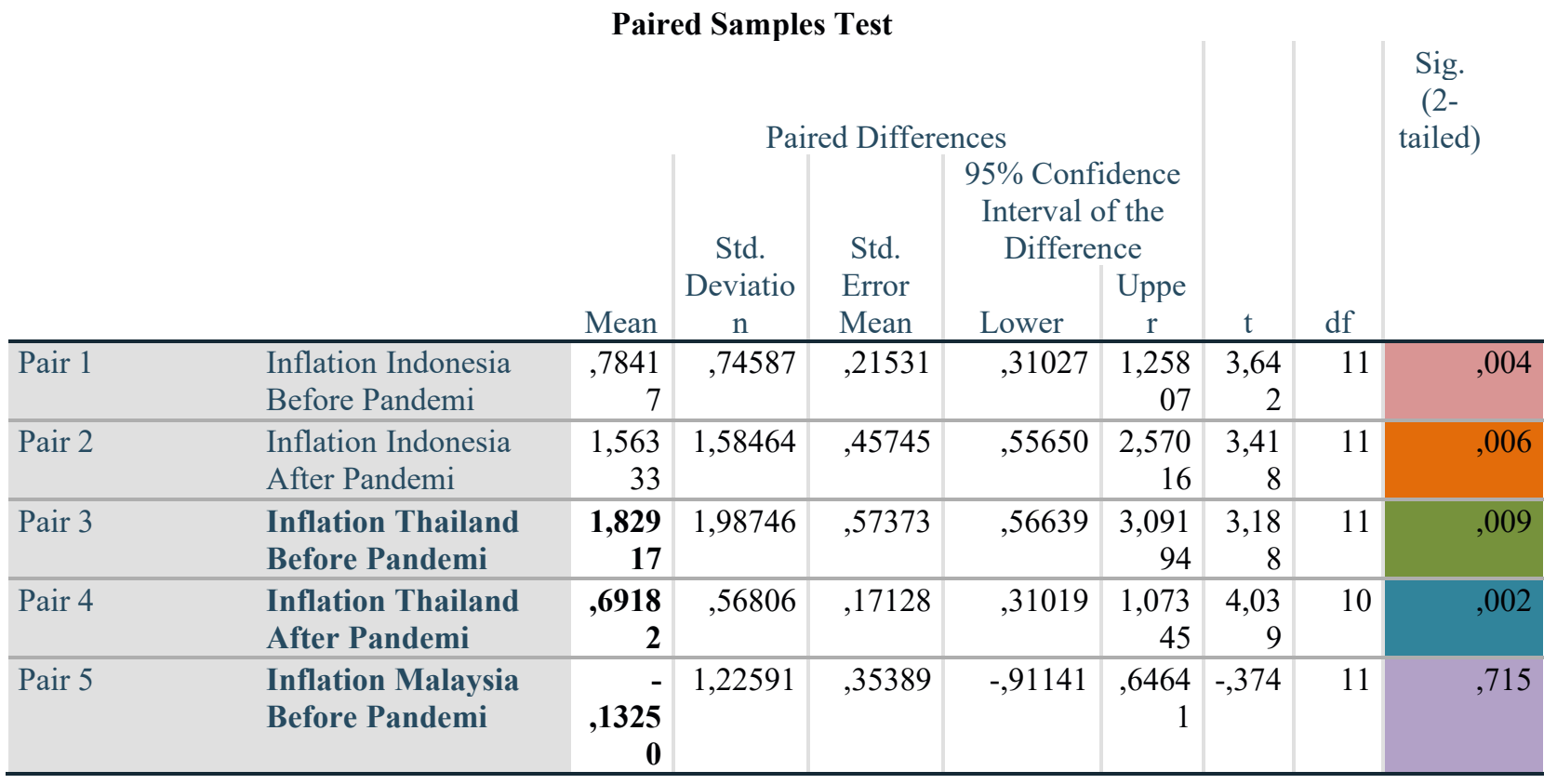

Sumber: Output Eviews 2021

Berdasarkan output dari bantuan program SPSS 25 di atas maka diperoleh hasil sebagai berikut :

The average inflation rate in Indonesia before the COVID-19 pandemic was $2.82 \%$ and during the pandemic the inflation rate decreased to $2.04 \%$. The sig (2-tailed) value for Indonesia's inflation variable (INF) is 0.00 , which means $<=0.05$. This shows that there is a significant difference in inflation before and during the COVID-19 pandemic in Indonesia. The average inflation rate in Thailand before the COVID-19 pandemic was $0.71 \%$ and during the pandemic the inflation rate decreased sharply to $-0.85 \%$. The sig (2-tailed) value for Thailand's inflation variable (INF) is 0.01 , which means $<=0.05$. This shows that there is a significant difference in inflation before and during the COVID-19 pandemic in Thailand.

The average inflation rate in Malaysia before the COVID-19 pandemic was $0.75 \%$ and during the pandemic the inflation rate decreased to $-1.08 \%$. The sig (2-tailed) value for the Malaysian inflation variable (INF) is 0.01 , which means $<=0.05$. This shows that there is a significant difference in inflation before and during the COVID-19 pandemic in Malaysia. The average inflation rate in Singapore before the COVID-19 pandemic was $0.53 \%$ and during the pandemic the inflation rate decreased to $-0.16 \%$. The sig (2-tailed) value for Singapore's inflation variable (INF) is 0.00 , which means $<=0.05$. This shows that there is a significant difference in inflation before and during the COVID-19 pandemic in Singapore. The average inflation rate in the Philippines before the COVID-19 pandemic was $2.50 \%$ and during the pandemic the inflation rate increased to $2.63 \%$. The sig (2-tailed) value for the Philippines inflation variable (INF) is 0.72 , which means $>=0.05$. This shows that there is no significant difference in inflation before and during the COVID-19 pandemic in the Philippines.

Tabel 4.2. Output $t$ test of Inflation

Paired Samples Statistics

\begin{tabular}{llrr|r|r} 
& & \multicolumn{2}{c}{ Paired Samples Statistics } & & \\
& & Mean & $\mathrm{N}$ & Std. Deviation & Std. Error Mean \\
\hline Pair 1 & Inflation ASEFO before pandemi & 1,4780 & 59 & 1,18727 &, 15457 \\
\cline { 2 - 6 } & Inflation ASEFO after pandemi &, 5264 & 59 & 1,80257 &, 23467 \\
\hline
\end{tabular}

Paired Samples Test Paired Differences

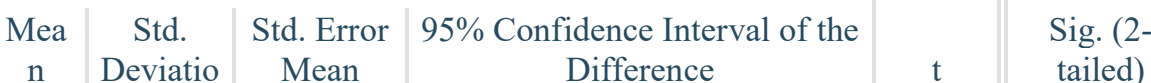




\begin{tabular}{llr|r|r|r|r|r||r} 
& & $\mathrm{n}$ & & Lower & Upper & \\
\hline Pair & $\begin{array}{l}\text { Inflation ASEFO before } \\
\text { pandemi }\end{array}$ &, 951 & 1,47312 &, 19178 &, 56763 & 1,33542 & 4,961 &, 000 \\
\hline $\begin{array}{l}\text { Inflation ASEFO after } \\
\text { pandemi }\end{array}$ & 53 & & & & & & \\
\hline
\end{tabular}

Source: Output Eviews 2021

Based on the output, it was found that the average inflation rate in ASEFO countries before the covid 19 pandemic was $1.48 \%$ and during the pandemic the inflation rate decreased sharply to $0.53 \%$. The value of sig (2-tailed) for the inflation variable (INF) in the ASEFO country is 0.00 , which means $<=0.05$. Thus, based on the criteria for acceptance and rejection of the hypothesis, it is known that $\mathrm{H} 0$ is rejected and Ha is accepted. This shows that there is a significant difference in inflation before and during the COVID-19 pandemic in ASEFO countries.

Tabel 4.3. Output t test Non Performing Loans

Paired Samples Statistics

\begin{tabular}{ll|r|r|r|r} 
& & Mean & $\mathrm{N}$ & Std. Deviation & Std. Error Mean \\
\hline Pair 1 & NPL Indonesia before Pandemi & 2,5983 & 12 &, 08397 &, 02424 \\
\cline { 2 - 6 } & NPL Indonesia after Pandemi & 3,0292 & 12 &, 17707 &, 05112 \\
\hline Pair 2 & NPL Thailand before Pandemi & 2,9750 & 12 &, 13853 &, 03999 \\
\cline { 2 - 6 } & NPL Thailand after Pandemi & 3,0517 & 12 &, 14758 &, 04260 \\
\hline Pair 3 & NPL Malaysia before Pandemi & 1,5575 & 12 &, 05154 &, 01488 \\
\cline { 2 - 6 } & NPL Malaysia after Pandemi & 1,5000 & 12 &, 07804 &, 02253 \\
\hline Pair 4 & NPL Singapura before & 1,4725 & 12 &, 28423 &, 08205 \\
& Pandemi & & & &, 05160 \\
\hline \multirow{2}{*}{ Pair 5 } & NPL Singapura after Pandemi & 2,2208 & 12 &, 06674 &, 01927 \\
\hline & NPL Filipina before Pandemi & 2,1200 & 12 &, 53899 &, 15559 \\
\hline
\end{tabular}

Paired Samples Test

\begin{tabular}{|c|c|c|c|c|c|c|c|c|c|}
\hline & & & Pairec & Samples 1 & & & & & \\
\hline & & & & Paired Dif & erences & & & & \\
\hline & & & $\begin{array}{c}\text { Std. } \\
\text { Deviatio }\end{array}$ & Std. Error & $\begin{array}{r}95 \% \text { Confid } \\
\text { of } \\
\text { Diffe }\end{array}$ & $\begin{array}{l}\text { e Interval } \\
\text { ce }\end{array}$ & & & $\begin{array}{l}\text { Sig. } \\
(2-\end{array}$ \\
\hline & & Mean & $\mathrm{n}$ & Mean & Lower & Upper & $\mathrm{t}$ & df & tailed) \\
\hline $\begin{array}{l}\text { Pair } \\
1\end{array}$ & $\begin{array}{l}\text { NPL Indonesia before } \\
\text { Pandemi }\end{array}$ & , & , 16719 & 04826 &,- 53706 &,- 32460 & $\begin{array}{r}- \\
8,92 \\
6\end{array}$ & 11 &, 000 \\
\hline $\begin{array}{l}\text { Pair } \\
2\end{array}$ & $\begin{array}{l}\text { NPL Indonesia after } \\
\text { Pandemi }\end{array}$ & , 07667 & ,25010 & ,07220 &,- 23557 & ,08224 & $\begin{array}{r}- \\
1,06 \\
2\end{array}$ & 11 & ,311 \\
\hline $\begin{array}{l}\text { Pair } \\
3\end{array}$ & $\begin{array}{l}\text { NPL Thailand before } \\
\text { Pandemi }\end{array}$ &, 05750 & , 12542 &, 03620 &,- 02219 & ,13719 & $\begin{array}{r}1,58 \\
8\end{array}$ & 11 &, 141 \\
\hline $\begin{array}{l}\text { Pair } \\
4\end{array}$ & $\begin{array}{l}\text { NPL Thailand after } \\
\text { Pandemi }\end{array}$ & , 74833 & ,28203 & ,08142 &,- 92753 &,- 56914 & $\begin{array}{r}- \\
9,19 \\
1\end{array}$ & 11 &, 000 \\
\hline $\begin{array}{l}\text { Pair } \\
5\end{array}$ & $\begin{array}{l}\text { NPL Malaysia before } \\
\text { Pandemi }\end{array}$ & , & ,51072 & 14743 &,- 97616 &,- 32717 & $\begin{array}{r}- \\
4,42 \\
0\end{array}$ & 11 & ,001 \\
\hline
\end{tabular}

Source: Output Eviews 2021

The average rate of Non Performing Loans (NPL) in Indonesia before the COVID-19 pandemic was $2.60 \%$ and during the pandemic the Non Performing Loans (NPL) rate increased to 3.03\%. The sig (2-tailed) value for the Indonesian Non Performing Loans (NPL) variable is 0.00 , which means $<=0.05$. This shows that there are significant differences in Non Performing Loans (NPL) before and during the COVID-19 pandemic in Indonesia. The average rate of Non Performing Loans (NPL) in Thailand before the COVID-19 pandemic was $2.98 \%$ and during the pandemic the Non Performing Loans (NPL) rate increased slightly to $3.05 \%$. The value of sig (2-tailed) for Thailand's Non Performing Loans (NPL) variable is 0.31 which means $>=0.05$. This shows that there is no significant difference in Non Performing Loans (NPL) before and 
during the COVID-19 pandemic in Thailand. The average rate of Non Performing Loans (NPL) in Malaysia before the COVID-19 pandemic was $1.56 \%$ and during the pandemic the number of Non Performing Loans (NPL) decreased to $1.50 \%$. The sig (2-tailed) value for the Malaysian Non Performing Loans (NPL) variable is 0.14 which means $>=0.05$.

This shows that there is no significant difference in Non Performing Loans (NPL) before and during the COVID-19 pandemic in Malaysia. The average rate of Non Performing Loans (NPL) in Indonesia before the COVID-19 pandemic was $1.47 \%$ and during the pandemic the number of Non Performing Loans (NPL) increased sharply to $2.22 \%$. The sig (2-tailed) value for the Singapore Non Performing Loans (NPL) variable is 0.00 , which means $<=0.05$. This shows that there are significant differences in Non Performing Loans (NPL) before and during the COVID-19 pandemic in Singapore. The average rate of Non Performing Loans (NPL) in the Philippines before the COVID-19 pandemic was $2.12 \%$ and during the pandemic the number of Non Performing Loans (NPL) increased to $2.77 \%$. The sig (2-tailed) value for the Philippines' Non Performing Loans (NPL) variable is 0.00 , which means $<=0.05$. This shows that there are significant differences in Non Performing Loans (NPL) before and during the COVID-19 pandemic in the Philippines.Berikut hasil olah data dengan bantuan program SPSS 25 untuk kondisi Non Performing Loans (NPL) sebelum dan selama masa pandemi secara umum di negara ASEFO :

Tabel 4.4. Output $t$ test Non Performing Loans

Paired Samples Statistics

\begin{tabular}{ll|r|r|r|r} 
& \multicolumn{1}{c}{ Mean } & N & Std. Deviation & \multicolumn{1}{c}{ Std. Error Mean } \\
\hline Pair 1 & $\begin{array}{l}\text { NPL ASEFO before } \\
\text { pandemi }\end{array}$ & 2,1447 & 60 &, 60457 &, 07805 \\
$\begin{array}{l}\text { NPL ASEFO after } \\
\text { pandemi }\end{array}$ & 2,5147 & 60 &, 64698 &, 08352 \\
\hline
\end{tabular}

Paired Samples Test

\begin{tabular}{|c|c|c|c|c|c|c|c|c|c|}
\hline & \multicolumn{6}{|c|}{ Paired Differences } & \multirow[b]{5}{*}{$\mathrm{t}$} & \multirow[b]{5}{*}{ df } & \multirow[b]{5}{*}{ Sig. (2-tailed) } \\
\hline & & \multirow[b]{4}{*}{ Mean } & \multirow{4}{*}{$\begin{array}{c}\text { Std. } \\
\text { Deviation }\end{array}$} & \multirow{4}{*}{$\begin{array}{l}\text { Std. } \\
\text { Error } \\
\text { Mean }\end{array}$} & \multirow{2}{*}{\multicolumn{2}{|c|}{$\begin{array}{l}95 \% \text { Confidence } \\
\text { Interval of the Difference }\end{array}$}} & & & \\
\hline & & & & & & & & & \\
\hline & & & & & & Uppe & & & \\
\hline & & & & & Lower & $\mathrm{r}$ & & & \\
\hline Pair & NPL ASEFO before & - & 42888 & 05537 &,- 48079 & - & - & 59 & 000 \\
\hline & pandemi &, 3700 & & & & ,2592 & 6,68 & & \\
\hline & & 0 & & & & 1 & 3 & & \\
\hline & $\begin{array}{l}\text { NPL ASEFO after } \\
\text { pandemi }\end{array}$ & & & & & & & & \\
\hline
\end{tabular}

Based on the output of the SPSS 25 program assistance above, it is obtained that the average rate of Non Performing Loans (NPL) in ASEFO countries before the COVID-19 pandemic was $2.14 \%$ and during the pandemic the number of Non Performing Loans (NPL) increased to $2.51 \%$. The sig (2-tailed) value for the Non Performing Loans (NPL) variable is 0.00 , which means $<=0.05$. Thus, based on the acceptance criteria and the hypothesis above, from the results table it can be seen that $t$ count at sig (2-tailed) $=0.02<=0.05$, the value of sig is smaller than the error level of 5\%. So, Ha is accepted and $\mathrm{H} 0$ is rejected. This shows that there are significant differences in Non Performing Loans (NPL) before and during the COVID-19 pandemic in ASEFO countries.

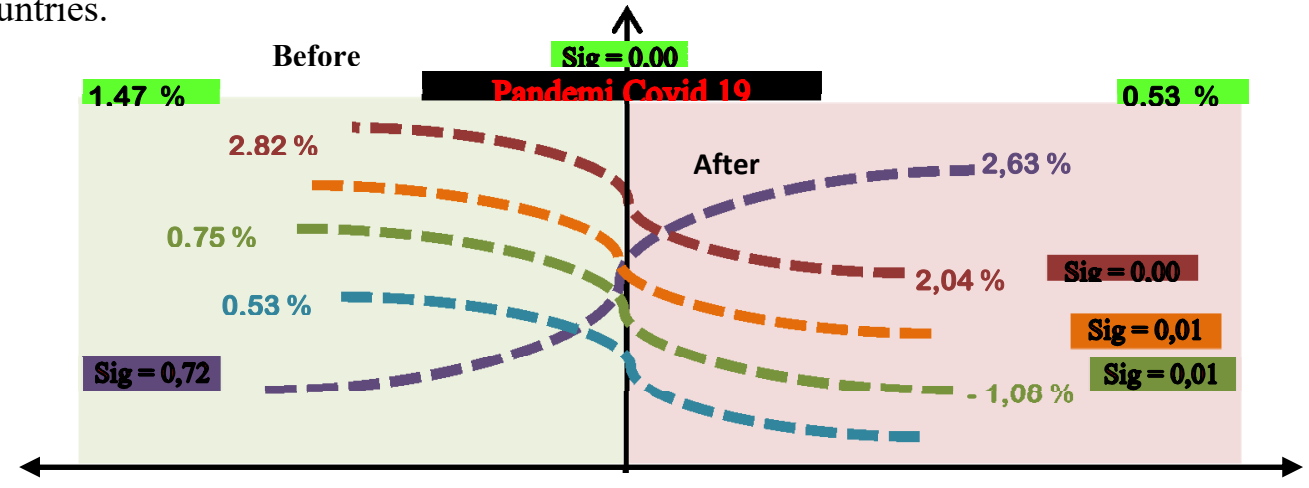


$\begin{array}{ll} & =\text { Inflation ASEFO } \\ & =\text { Indonesia } \\ & =\text { Singapura } \\ & =\text { Thailand } \square=\text { Filipina } \\ & =\text { Malaysia }\end{array}$

Fig 4.1. $T$ Test Inflation

During the pandemic, inflation rates in Indonesia, Thailand, Malaysia and Singapore decreased and the results also showed that there were significant differences in inflation before and during the COVID-19 pandemic in these four countries. This inflation rate condition is influenced by the negative impact of the COVID-19 pandemic on the ASEFO country's economy. Where the decline in the rate of household consumption during the pandemic limited demand pull inflation pressures and created the potential for a slowdown in the domestic economy, especially in Malaysia, where the government is very firm in implementing a regional lockdown policy, so that inflationary pressure in the country is quite large. Meanwhile, in terms of supply-push inflation, the government's policy of imposing physical distancing and the potential for regional quarantine in several regions in the four regions of the country may cause disruption to the distribution of goods and services in general. Hanoatubun's research (2020) states that the COVID-19 pandemic has made it increasingly difficult to find jobs, decrease income and fulfill daily needs. This condition certainly causes low purchasing power of the people, so that the volume of demand for goods and services decreases and causes a low level of inflation.

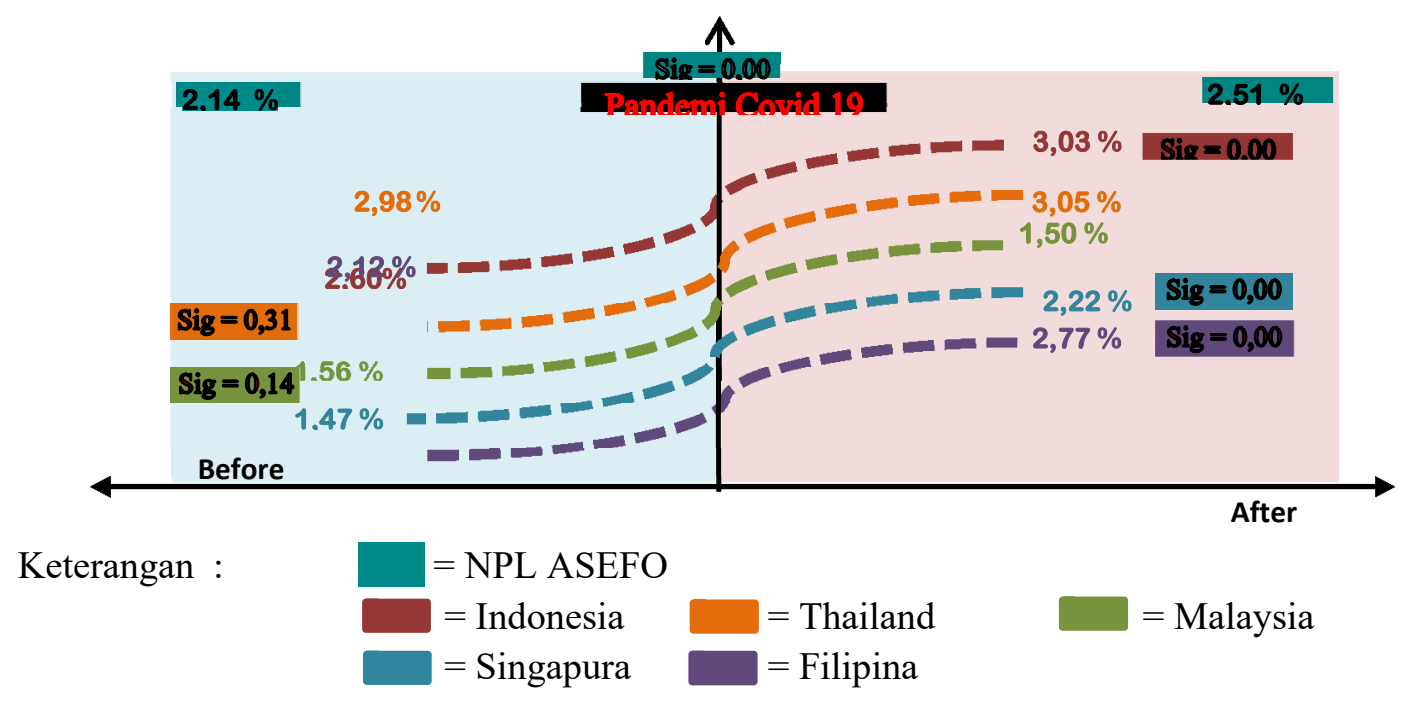

Fig 4.2. $\mathrm{T}$ Test Non Performing Loans (NPL)

During the pandemic the number of Non Performing Loans (NPL) of Indonesia, Singapore and the Philippines increased and the results also showed that there were significant differences in Non Performing Loans (NPL) before and during the covid 19 pandemic of the three ASEFO countries. However, when compared to the credit risk value during the 1997 and 2008 crises, the credit risk value in the midst of the COVID-19 pandemic is still relatively safe. During the COVID-19 pandemic, the number of debtors who had difficulty making credit payments continued to increase. The increase in the number of bad loans is also very high because many debtors are unable to pay their installments on time and are not even able to repay their debts in full (Bidari et al, 2020).

The hampered credit growth is in line with the decline in economic activity as a result of the implementation of the Large-Scale Social Restrictions (PSBB). Azimah's research (2020) which states that the emergence of the COVID-19 pandemic caused the economy to experience a decline, especially for market traders who experienced a 50\% decrease in turnover and income. This condition of decreasing operating profit will increase the risk of non-performing loans in the community. Even this credit risk value has the potential to continue to increase. This can happen if credit distribution continues during the pandemic without considering credit quality. If this credit distribution is not focused on the principle of prudence, it can harm the banking industry. This modest increase in credit risk is one of the positive impacts of relaxation on MSME loans. However, it will not be able to withstand the volatility of risk in the long term. This result is 
also in line with Tiwu's research (2020) which states that the COVID-19 pandemic has a significant effect on NPLs at Rural Banks in Indonesia.

\section{CONCLUTION}

For general inflation conditions in ASEFO countries, the results show that during the pandemic the inflation rate declined sharply and there was a significant difference in inflation before and during the COVID-19 pandemic in ASEFO countries. During the pandemic the number of Non Performing Loans (NPL) of Indonesia, Singapore and the Philippines increased and the results also showed that there were significant differences in Non Performing Loans (NPL) before and during the COVID-19 pandemic in Indonesia. During the pandemic the number of Non Performing Loans (NPL) in Thailand and Malaysia increased, but the results showed that there was no significant difference in Non Performing Loans (NPL) before and during the COVID-19 pandemic in Thailand. For the condition of Non Performing Loans (NPL) in general in ASEFO countries the results show that during the pandemic NPL has increased and there are significant differences in Non Performing Loans (NPL) before and during the covid 19 pandemic in ASEFO countries.

\section{DAFTAR PUSTAKA}

[1] Anwar,C.J., Sunaenah (2016). Pengaruh ROA dan CAR Terhadap Kredit Macet (NPL) Pada Bank Umum Di Indonesia, Jurnal Ekonomi-Qu, 6(2), Hal: 214-235

[2] Novalina, et al. (2020). Model Seemingly Unrelated Regression Stabilitas Ekonomi Melalui Combined Policy Fiskal Moneter Di Indonesia. Jurnal Kajian Ekonomi dan Kebijakan Publik, 5(1), Hal: 46-56

[3] Nurlina, Zurjani (2018). Dampak Kebijakan Fiskal dan Moneter dalam Perekonomian Indonesia. Jurnal Samudra Ekonomika, 2(2), Hal: 126-136

[4] Rosya, N., Amar, S., \& Syofyan, E. (2013). Analisis Penawaran Agregat Dan Permintaan Agregat Di Sumatera Barat. Jurnal Kajian Ekonomi, 2(3), Hal:66-84

[5] Santoso, T., \& Basuki, U. (2009). Dampak Kebijakan Fiskal Dan Moneter Dalam Perekonomian Indonesia: Aplikasi Model Mundell-Fleming. Jurnal Organisasi dan Manajemen, 5(2), hal:108-128

[6] Seprilina, Linda, Ghozali Maskie dan Moh Khusaini (2016). Analisis Respon Kebijakan Moneter dan Kebijakan Makroprudensial dalam Mekanisme Transmisi Kebijakan Moneter Jalur Kredit di Indonesia. International Journal of Social and Local Economic Governance (IJLEG), 2(1), Hal: 1-12

[7] Siregar, Hermanto, dan Ward, Bert D (2002). Were Aggregate Demand Shocks Important in Explaining Indonesian Macroeconomic Fluctuations?. Journal of the Asia Pacific Economy. 7, Hal: 35-60

[8] Sukirno, Sadono. 2011. Makro Ekonomi Teori Pengantar Edisi Ketiga. Jakarta: Rajawali Pers

[9] Utami, Pratiwi. J. (2013). Analisis faktor yang mempengaruhi permintaan kredit pemilikan rumah pada bank umum di Kota Makassar. Makassar: Universitas Hasanudin

[10] Wardhana, D. (2020). Kajian Kebijakan Dan Arah Riset Pasca-Covid-19. The Indonesian Journal Of Development Planning, 4(2), Hal: 223-239

[11] Warsa, .N. M. I. U. P, Mustanda, I.K. (2016). Pengaruh CAR, LDR Dan NPL Terhadap Roa Pada Sektor Perbankan Di Bursa Efek Indonesia. E-Jurnal Manajemen Unud, 5(5), Hal: 2842-2870

[12] Widyastuti, N. (2017). Dampak kebijakan moneter pada output di negara-negara ASEAN tahun 1980-2014. Jurnal Riset Manajemen, 4(1), hal:58-70

[13] Yeni, P., Amar, S., Satrianto, A. (2018). Pengaruh Suku Bunga, Loan to deposit ratio (LDR) dan Pertumbuhan Kredit terhadap Inflasi di Indonesia. Ecogen, 1(3), Hal: 557-566 